ISSN: 2224-0616

Int. J. Agril. Res. Innov. Tech. 11(1): 37-48, June 2021

DOI: https://doi.org/10.3329/ijarit.v11i1.54465
OPEN 2 ACCESS

Available online at https://ijarit.webs.com https://www.banglajol.info/index.php/IJARIT

\title{
Analysis of beef cattle marketing channels under transaction costs in rural Ethiopia
}

\author{
A. Dinku ${ }^{*}$, B. Abebe ${ }^{2}$, A. Lemma ${ }^{1}$ and M. Shako ${ }^{1}$ \\ Received 10 March 2021, Revised 5 May 2021, Accepted 23 June 2021, Published online 30 June 2021
}

\begin{abstract}
A B S T R A C T
The study was designed to analyze beef cattle marketing channel choice under transaction costs. Multistage sampling technique was used to acquire primary data. Data were analyzed using descriptive statistics and the Multinomial Logit Model. The findings verified that most of the respondents $(49 \%)$ were selling at the village markets, followed by farm gate and secondary market with $28 \%$ and $23 \%$, respectively. The model results revealed that the probability of selling at farm gate and village market versus selling at secondary market increased with season sales, indicating level of market uncertainty. The results affirmed the probability of selling at village market versus selling at secondary market outlet increased with knowledge of buyer and decreased with trust in buyers. Other significant predictors were volume of beef cattle supplied, farmers' experience, and education level. Thus, policies aimed at improving the smallholder farmers' access to cattle marketing channels should be informed by these factors.
\end{abstract}

Keywords: Beef cattle, Marketing channel choice, Multinomial logit model, Smallholder farmers, Transaction cost.

${ }^{1}$ Department of Agricultural Economics, College of Agriculture, Oda Bultum University, P. O. Box 226, Chiro, Ethiopia.

${ }^{2}$ Department of Animal Science, College of Agriculture, Oda Bultum University, P. O. Box 226, Chiro, Ethiopia.

*Corresponding author’s email: adunedinku@gmail.com (Adunea Dinku)

Cite this article as: Dinku, A., Abebe, B., Lemma, A. and Shako, M. 2021. Analysis of beef cattle marketing channels under transaction costs in rural Ethiopia. Int. J. Agril. Res. Innov. Tech. 11(1): 37-48. https://doi.org/10.3329/ijarit.v11i1.54465

\section{Introduction}

Smallholder farmer's access to the output market is believed to an essential part of market participation thereby the significant potential for rural development in developing countries including Ethiopia. According to the comparative advantage school of thought, trade has static welfare effects in addition to welfare gains of market participation that accrues from largerscale production opportunities in the face of excessive fixed costs, effects of technological change in usual market-based exchanges, and the related total factor growth in productivity (Barrett, 2008). Encouraging agricultural producers and mainly smallholder farmers towards market-oriented production systems in developing countries are central for the development of successful agribusiness value chains and supply of adequate food. This involves improvement in production and marketing practices to enhance income-generating capacity among resource-poor farming households (Otieno et al., 2009).

A farmer can have access to the output market mainly through two means i.e. either by directly selling to a purchaser at the farm gate or physically transporting to the output market. Many scholars have been studied about what force smallholder farmer's access to market and much has been discovered. For instance, Ruijs et al. (2004) and Jari and Fraser (2009) reported that good road conditions and access to market information positively influenced farmer participation and access to markets due to their effect on the decrease in transaction costs of marketing outputs.

Smallholder farmers' participation in the market can be a helpful way of moving out of miserable poverty and amplifying their income (IFAD, 2003). However, according to Barrett (2008), a smallholder farmer's market participation in developing countries is very low. This situation sluggish economic growth and exacerbated poverty levels in developing countries especially Ethiopia were their economy is agriculture driven. As a result, smallholder farmers cannot obtain benefits from the welfare gains and income escalation allied with market involvement. Hence, studies revealed that smallholder farmers have to commercialize their farming activities to produce marketable surpluses for agriculture, significantly add to the economic growth of the country (Jagwe et al., 2010). 
Smallholder farmers may also benefit from technological change effects from the improved flow of ideas from trade-based interactions (Barrett, 2008). As a result, there may be improved factor productivity for farmers. Regardless of the rivulet of benefits that are innate with participation in the output market, studies showed that smallholder farmers' participation in the output market is little owing to high transaction costs, asymmetries information, and institutional constraints among others. Siziba et al. (2011) and Barrett and Swallow (2006) argues that smallholder farmers need to have access to productive assets, adequate private and public investment, institutional and physical infrastructure to access remunerative markets. Besides, smallholder farmers with access to production, private and public sector goods, properly functioning institutions and well-developed physical infrastructure actively participate in markets contrary to their counterparts (Barrett, 2008).

Jorine et al. (2015) on their study to test the effects of information, negotiation, and monitoring costs on the household's decision to sell to private buyers, speculators or at auction unveiled some unique insights into cattle marketing behavior in South Africa. For instance, regarding information costs, they reported that market uncertainty during the off-peak season pushes smallholder farmers to self-select out of livestock auctions. They also found low bargaining power and high opportunity costs of time during the selling of the cattle to speculators and dip tank sales, respectively.

In Ethiopia, to improve the competitiveness of live animals and meat export, tremendous interventions in the coordination of livestock marketing activities and provision of market support services are needed. To attain efficient use of the sector, to ensure food security and improved export performance cost-effective marketing channels and coordinated supply chains, which reduce non-value adding transaction costs among different actors along the supply chain, are crucial. If livestock producers and exporters are to be competitive in both domestic and international markets, their value supply chains need to be more efficient and more effective (Teklewold et al., 2008).

Livestock markets in Ethiopia are scattered with distant markets missing price information. Besides, the quantity of livestock offered for sale in the local market is frequently larger than the quantity demanded, so there is a surplus in supply. Du to this the producer prices suppressed in the market given that the more mobile trader is up to date on market prices, while better information united with surplus supply put the trader in a better situation during price negotiation. Livestock is generally traded by 'eyeball' pricing, and weighing livestock is uncommon. Market prices are typically fixed by individual bargaining and depend mostly on supply and demand, which is profoundly influenced by the season of the year and the occasion of religious and cultural festivals. Ethiopia's livestock supply is heavily influenced by the severity of the dry season (Reddy and Kanna, 2015).

According to Reddy and Kanna (2015), livestock marketing system in Ethiopia is very complex, linking a number of different types of market actors as the marketed animals move from the producers to the processors or end-users. The different links in the market chain indicate the different services that are provided to deliver the livestock or meat to the various end-users. The overall structure of the cattle marketing system is quite complex which is characterized by major marketing costs at each stage. Marketing costs are composed of the total costs incurred on the marketing of products by each agent. It can be defined as the sum of charges paid for any marketing activity such as cost of transportation, and cost of capital invested in trading and transaction costs including fees paid to intermediaries, agents for entry and exit of animals, administrative charges as well as official and illicit taxes (Yacob and Catley, 2010).

Efforts are needed to increase cattle producers' bargaining power and specialization in cattle farming. As producers become more specialized in beef cattle production, producers bargaining power will increase when dealing with buyers (Gong et al., 2007). Therefore, producers recommended working collectively in the procurement of production inputs, managing all shared grazing land and infrastructure, obtaining all required production, marketing related information, and collectively marketing their livestock (Binti Man et al., 2017).

In various developing countries including Ethiopia, the operation of agricultural output markets is deterred by high transaction costs (Bassolet, 2000). Transaction costs, that is, the observable and non-observable costs associated with output exchange; act as the key blocks to market participation and choice of alternative marketing outlets for resource-poor farmers in the region (Makhura et al., 2001). In addition, poor infrastructure often increases such market transaction costs (Takeshima, 2008). The question of how agricultural producers arrived at the decision on choosing whether to sell their produce at the farm gate or to transport to the output market was getting slight consideration in the current literature. This is astonishing as of a policy and strategy outlook since the living of numerous poor farming communities in SubSaharan African countries in general and Ethiopia in particular relies on the trade of agricultural produce. With this backdrop, the study was designed to analyzed factors influencing smallholder farmers' choice of beef cattle marketing channels under transaction cost. Following the work of Hobbs (1997), the current study empirically scrutinizes the determinants based on transaction cost economics. 


\section{An overview of transaction cost approaches}

Many scholars define transaction costs differently. They generally understood as all costs related with the act of exchanging ownership rights of important assets. There is no standard definition of the phrase though suggest that transaction costs are mostly understand as costs associated with market exchange (Singh, 2008). In their study, Key et al. (2000) define transactions costs as fixed and proportional (variable) transactions costs. Following this concept, original search costs, negotiation and enforcement costs that are invariant to the volume of input as well as output are fixed transactions costs. In addition, Staal et al. (1997) classify transaction costs into observable and unobservable costs. The observable transaction costs include transport, handling, packaging, storage, and spoilage costs among others that are observable when a transaction happens. While unobservable transaction costs include cost of information seeking, bargaining, and enforcement of contracts among others (Staal et al., 1997).

Furthermore, many decades ago, Coase (1937) bring in the concept of transaction costs related with information, negotiation, monitoring, coordination, and enforcement of contracts. Since then, a number of literatures have been applied the transaction costs in agricultural markets. Based on the concept of Coase, Hobbs (1997) has classified the components of transactions costs in to information costs (costs arising before the transaction), negotiation costs (costs of physically carrying out the transaction) and monitoring costs (costs of ensuring that the terms of the transaction are hold).

In order to proceed with a transaction, producer must search for information and monitor the ongoing process to ensure a favorable deal. The costs involved in such transaction-related activities are called transaction costs. In economics and related disciplines, a transaction cost is a cost incurred in making an economic exchange (restated: the cost of participating in a market). Transaction costs can be divided into three broad categories [(Coase, 1937) as cited in (Binti Man et al., 2017)]: (i) Search and information costs are costs such as in determining that the required good is available on the market, which has the lowest price, etc. (ii) Bargaining costs are the costs required to come to an acceptable agreement with the other party to the transaction, drawing up an appropriate contract and so on. In game theory this is analyzed for instance in the game of chicken. On asset markets and in market microstructure, the transaction cost is some function of the distance between the bid and ask. (iii) Policing and enforcement costs are the costs of making sure the other party sticks to the terms of the contract, and taking appropriate action (often through the legal) if this turns out not to be the case.
Transaction costs are considered as obstacles to the efficient participation of farmers in diverse markets. As a result, farmers will not use a particular channel when the value of using that channel is offset by the costs of using it (Musemwa et al., 2008). The study affirmed that market transactions do not take place in a frictionless environment (De Bruyn et al., 2001). Thus, transaction costs are economically equivalent to frictions in physical systems (MacInnis, 2004). In addition, transaction costs are exclusive and specific to individual agents in the market; as a result, each agent in the market conducts transactions based on his/her own costs (Jabbar et al., 2008).

Economic agents face costs in seek for market information about products, prices, inputs and buyers or sellers (Hobbs, 1996). The extent of readily available of market prices information determines the costs of obtaining it (Hobbs, 1997). Accordingly, the more time and energy spent on searching for market information, the higher the information cost (Gong et al., 2007).

Negotiation costs arise from the physical act of the transaction and are influenced by the way in which the transaction is carried out (Binti Man et al., 2017). The study illustrated that opportunity cost of the time that procurement staff takes to locate supplies of cattle is a negotiation cost (Hobbs, 1996). Besides, it is indispensable to monitor the quality of goods from a supplier or to monitor the activities of a supplier (or buyer) to guarantee that all pre-agreed conditions of the transaction are meet the terms with (Hobbs, 1996). Particularly, cattle producers may incur the monitoring costs in guarantying that the cattle are handled properly all through transportation to the market place and buyer locations. If there is an intension amongst cattle purchaser that the cattle are highly stressed or have been injured due to extra management and transportation, they may reduce the prices that they are primed to pay for cattle (Binti Man et al., 2017).

\section{Methodology \\ Study area description}

This study was conducted in Western Hararghe Zone, Oromia National Regional State, Ethiopia. From the Zone, the trailer districts, that is, the districts of Gemechis and Doba were selected based on their intensity of beef cattle production and marketing activities. Gemechis district is located $343 \mathrm{~km}$ east of Addis Ababa and about 17 $\mathrm{km}$ south of Chiro, capital of the Zone. It is found between 1300 and 2400 m.a.s.l. The district covers an area of 77,785 ha and has 35 rural kebeles and one urban. Agro ecologically, the district has highlands (15\%), midland (45\%) and floodplain (40\%) and receives average annual bimodal rainfall of $850 \mathrm{~mm}$ (GDOA, 2014). The 
average temperature of the district is 20 oc. The district's projected total population is 235,638 (CSA, 2017). The number of agricultural households in the district is estimated at 38,500 (GDOA, 2014).

The District of Doba is located $382 \mathrm{~km}$ east of Addis Ababa and $45 \mathrm{~km}$ from Chiro, the zonal capital. The district has 33 rural kebeles and 3 rural towns. The district has an altitude ranging from 1400 to 2500 m.a.s.l. Agro ecologically, the district has highlands (dega) 40\%, highlands (weyna dega) 57\% and lowlands (kola) 3\%. The district receives average bimodal annual rainfall ranging from $550 \mathrm{~mm}$ to $800 \mathrm{~mm}$ and has average daily temperature ranging from $18^{\circ} \mathrm{C}$ to $26^{\circ} \mathrm{C}$ (DDOA, 2014). The district's projected total population is 171,458 (CSA, 2017). In this medium, 166,181 populations are leaving rural areas through the conduct of their livelihoods from agriculture and related activities.

\section{Research design}

The design of the research used was the crosssectional and descriptive survey. Through this design, a mixed approach (quantitative and qualitative approach) was used to overcome the disadvantages of using a single approach and help to take its complementarities, thus capturing pertinent information to address the research objectives. The quantitative method involves data collection procedures that resulted mainly in numerical data that were analyzed using statistical methods. On the contrary, the qualitative approach involves data collection procedures that resulted mainly in open and nonnumerical data, and, therefore, analyzed through conceptualization.

\section{Sampling procedures}

For this particular study, multiple-stage sampling procedures were used. In the first stage, the District of Doba and Gemechis was selected with based on the potential (predominant producers) beef cattle production and intensity of market participation. In the second stage, as not all kebeles are uniform, potential kabeles were identified and listed from both districts. Then, six kebeles were randomly selected with probability proportional to the size of the kebeles identified from two districts. In the third stage, the sample households of each kebeles were selected. To select the sample households, a systematic sampling technique was applied, taking the $\mathrm{n}^{\text {the }}$ element of the listed households. There are 2098 households in six selected kebeles. The list of households was received from the selected kebeles office and updated to the current status. 2098 was divided by sample size (186) and gives 12. Therefore, the value of $n$ is 12 . A number was randomly obtained between 1 and 12. The number was seven. So that, every $12^{\text {numbers, }}$ it would be selected to be sampled at home. In addition, it promises that the population has been uniformly sampled.

\section{Sample size determination}

To fix the sample size, a suggested quantitative formula (Yamane, 1967) was adopted as indicated here in:

$\mathrm{n}=\frac{\mathrm{N}}{1+\mathrm{N}(\mathrm{e} 2)}$

When $\mathrm{n}$ sample size (sample size in each kebele was selected based on its proportion to $\mathrm{N}$, since the number of households in each kebele is different); $\mathrm{N}$ total number of households in the selected kebeles and maximum variability or margin of error $9 \%$ (0.09). Based on the result of determining the sample size above, 186 respondents were acquired from the sample. Thus, considering the available resource and the representativeness of the acquired sample, the total sample size of the producer for the study was reduced to 171 .

\section{Data type and sources}

To explore the research objectives, primary and secondary data sources were used. Primary data were collected from head of household sour cattle and their respective district and zonal officers through semi-structured questionnaires and checklists prepared for this purpose, respectively. Secondary data, including published and nonpolished documents available and relevant to this study, were collected to substantiate the primary data. In addition, personal observation was made about different aspects of beef cattle management and marketing activities during the research period to obtain broad-spectrum information.

\section{Method of data collection}

The main instrument used for the collection of primary data was the schedule of semi-structured interviews. Trained enumerators through face-toface interviews administered the questionnaire with the interviewees. The questionnaires were pre-tested in a select area similar to the study site in ten randomly selected interviewees to ensure their validity and reliability in generating the indispensable data. Thus, necessary changes were made before the formal investigation was carried out. After the pre-test, two days of training were given to enumerators on briefings of the objectives, contents of the questioners of the interview and to familiarize them with the basic techniques of data collection. Enumerators were selected based on their educational background and data collection experience, local knowledge and ability to speak local language. The interview questions were focused on demographic, socioeconomic, institutional and transaction costs.

Subsequently, the research was carried out under the close supervision and assistance of the researchers. An FGD consists of a people from different backgrounds were conducted in each 
kebeles selected to obtain in-depth information and fill in the gaps observed during personal interviews. In addition, KII was conducted with experienced people to obtain general information on transaction costs related to cattle marketing activities using a checklist prepared for this purpose. The main participants were including extension agents, model farmers in relation to the beef cattle business and zonal and district officials.

\section{Method of data analysis}

After the completion of the fieldwork, the data were coded and inserted into the Software Statistical Package for Social Science (SPSS) version 20. As of now, the data has been cleaned up and confirmed for analysis. The qualitative data generated through the Discussion of the Focal Group and the key informants were analyzed through a narrative approach after thematic categorization following the research objective. This was done immediately after data collection. Quantitative data generated through personal interviews and questionnaires were analyzed using STATA software version 12 after the import of SPSS software. Then, research results were presented in the form of a table format.

Too effectively handle and analyze the diverse data collected from the field and producers, mixture of different descriptive analysis methods (frequencies, percentages, means etc.) and econometrics models such as multinomial logit model was used. Among others, Multivariate probit/logit (MVP/L), different scholars for the studies commonly suggest Multinomial logit (MNL) and Multinomial probit (MNP) regression models that involves multiple choices (Hausman and Wise, 1978; Wu and Babcock, 1998).

However, multivariate probit model considers the interdependent and simultaneous choice decisions of various channels (Arinloye et al., 2015; and Degye et al., 2013). Hence, binary probit/ Logit/ and Multinomial probit/ Logit/ models did not consider the possible interrelationships between the various market channels ( $\mathrm{Yu}$ et al., 2008). The advantage of using a MNL model is its computational simplicity in calculating the choice probabilities that are expressible in an analytical form (Tse, 1987). This model provides a convenient closed form for underlying choice probabilities, with no need for multivariate integration, making it simple to compute choice situations characterized by many alternatives. In addition, the computational burden of the MNL specification is made easier by its likelihood function, which is globally concave (Hausman and McFadden, 1984).

The process for formulating a MNL model is similar to that of binary logistic regression (Dougherty, 1992). Yet, in binary logistic regression, the dependent variable has two categories while MNL model has more than two categories. Thus, MNL model is an extension of the binary logistic regression. The utilitymaximizing function stipulates that it can be realized that farmers make choices to produce, consume and market as subjected to many factors including market transaction costs (Jari and Fraser, 2009). As a result, choices to market produce in alternative output markets signify the direction which maximizes utility. The outcome variable captured three channels of cattle marketing, i.e. farm get sales, village/primary market sales, and secondary market outlets and where the latter serves as the reference channel in the model. Following prior studies, for instance those by Gong et al. (2006) and Shiimi et al. (2012), transaction cost variables are grouped into three main classes: information, negotiation, and enforcement costs, to which farmers' characteristics are included as control variables (Hobbs, 1997).

Therefore, the multinomial model was used in this paper to determine the likelihood of choosing farm get market outlet versus secondary market channels and village market channels versus secondary market channels under transaction costs approach. MNL model specification for market channel choice is as follows: It follows that Pi stand for the likelihood of choosing farm get sale and (1-Pi) stand for the likelihood of choosing village/primary market channels versus secondary market channels. The probability that the smallholder farmers' prefer one market channel compared to the other was limited to lie between zero and one $(\mathrm{o} \leq \mathrm{Pi} \leq 1)$. Thus, logit $(\mathrm{Pi})$ ranges from negative infinity to positive infinity (Gujarati, 1992).

Mathematically, the model was specified as revealed under: Let $A i$ be a random variable representing the market channel chosen by any smallholder farmers under transaction costs. The assumption is that each smallholder farmers' faces a set of discrete, mutually exclusive choices of market channels under transaction costs. These market channels are assumed to be depend on information, negotiation, enforcement costs and farmers characteristics X. The MNL model for choice of market channels under transaction costs specifies the following relationship between the probability of choosing option $\mathrm{Ai}$ and the set of explanatory variables $\mathrm{X}$ as described by Greene (2003):

$\operatorname{Prob}(A i=\mathrm{j})=\frac{e^{\beta j x i}}{\sum_{k=0}^{j} e^{\beta k x i}}, \mathrm{j}=0,1,2 \ldots \mathrm{j}$.

Where, $\beta \mathrm{j}$ is a vector of coefficients on each of the independent variables X. Equation (1) could be normalized to remove indeterminacy in the model by assuming that the probabilities could be estimated as: 
$\operatorname{Prob}(\mathrm{A} i=\mathrm{j} \mid \mathrm{Xi})=\frac{e^{\beta j x i}}{1+\sum_{k=1}^{j} e^{\beta k x i}}, \mathrm{j}=0,2 \ldots \mathrm{j}, \quad \beta O=0$

Estimating equation (3) gives the $\mathrm{J}$ log-odds ratios

$\ln \left(\frac{P i_{j}}{P i_{k}}\right)=X_{i}^{\prime}\left(\beta_{j}-\beta_{k}\right)=X_{i}^{\prime} \beta_{J}$, if $\mathrm{k}=\mathrm{o}$

\section{Consideration for ethical issues}

Prior to the start of research activities, the research design was explained to the respective study districts of the Department of Agriculture and Rural Development for their consent and help during the research period. In addition, the nature of the study was fully explained to the interviewees to obtain permission. No false promises, such as payment and or by diem, food and pecuniary aid were given. Thus, the data were collected after obtaining the permission of the research participants. The data obtained from the research participants were kept secret, and all respondents who participated in the study were accredited.

\section{Results and Discussion}

\section{Descriptive statistics analysis}

The result in Figure1 illustrated the most beef cattle marketing channels utilized in the study areas. The descriptive result indicated that most respondents (49\%) were selling at the village market outlets, followed by farm gate and secondary market outlet (reference category) sales with $28 \%$ and $23 \%$, respectively.

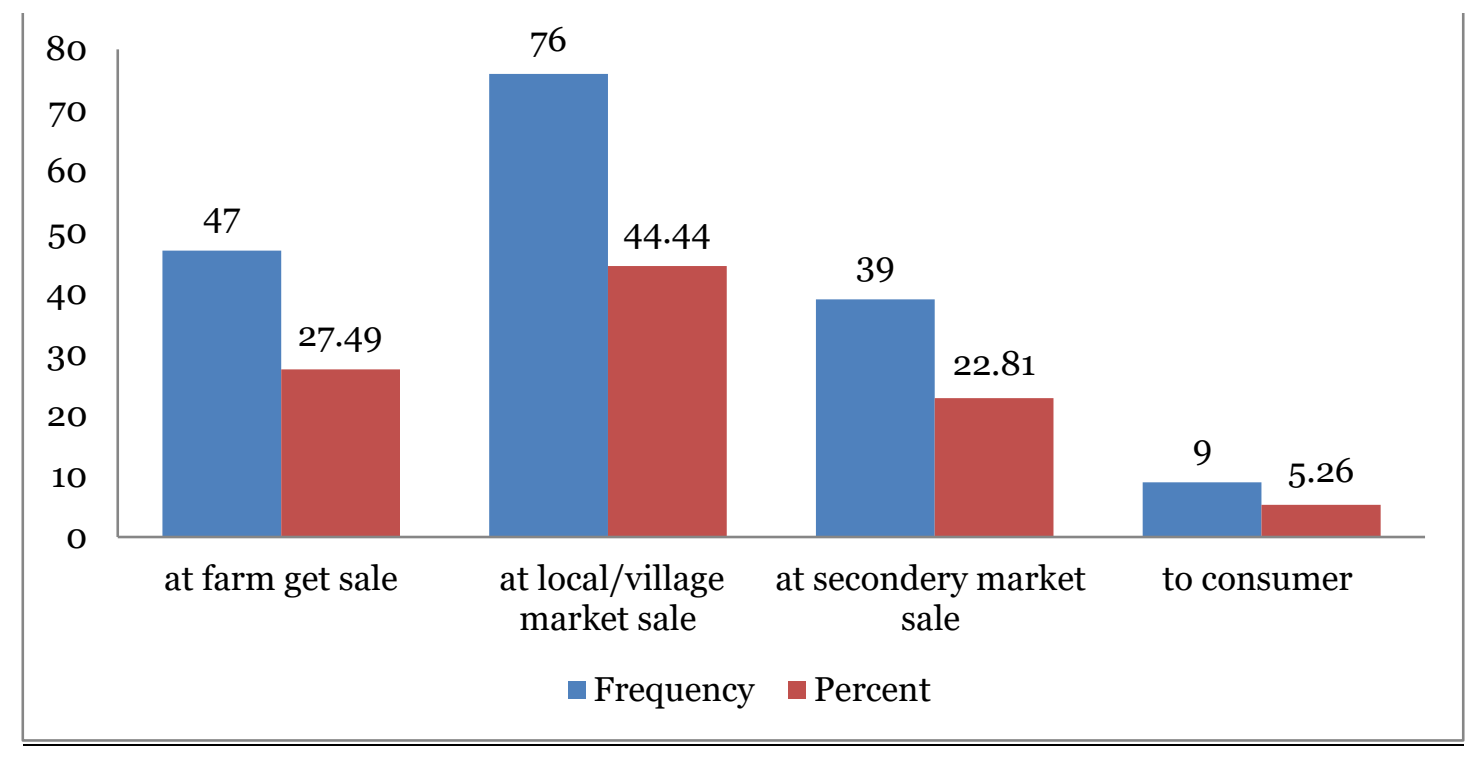

Fig. 1. Beef cattle marketing outlets mostly accessible.

All independent variables, as portrayed in Table 1 and 2, are chosen to be used for analysis by MNL regression model following the significance they contribute across all outcome categories in the model, i.e. the log-likelihood ratio (LR) test for independent variables (Wooldridge, 2002).

Information about existing market price (PRICEINFO) captures beef cattle price discovery costs. Different scholars at different times found that the cost of obtaining market price information depends on the degree to which market price information is readily accessible to producers (Shiimi et al., 2012; and Ndoro et al., 2014). As a result, a positive influence of accessibility of market price information on market beef cattle outlet selection was projected, principally for selling at farm gate versus selling at the village/secondary market outlet. A descriptive result in Table 1 demonstrates that, from interviewed respondents 51 (30.54) had no price information at all while the others had little 72 (43\%), somehow 32 (19.2\%), and fully 12 (7.2\%) market information.
The season during which beef cattle sale transaction took place (SEASONSALE) is a dummy variable capturing sales transacted in pick festival or holiday of the year or otherwise. This variable is mainly served as a sign of market price uncertainty in the MNL model. The study found that market price uncertainty is heightened if the producer is not sure about the number of buyers that will turn up at the market place (Hobbs, 1997). To the extent that the demand for beef peaks during the pick festival or holiday season, this variable was expected to affect the selection of beef cattle marketing outlets. The result in Table 1 depicted that most of the recorded sale transactions by respondents 103 (61.68\%) were take place during the pick season (festive or holiday months) of the year which shows high market uncertainty in the study areas.

The knowledge of the buyer (KNOWBUYER) captures the beef cattle producers' knowledge of the buyer all through beef cattle sales transactions. Hobbs (1997) argued that having a good relationship with the buyer in a certain 
marketing channel decreases the cost of negotiating sales, and hence may initiate a positive market outlet selection result. A priori expectation was a positive effect of this variable on the choice of farm-gate and village market sales versus primary market sales. The result depicted in Table 1points out that lower level of respondents' knows the buyers during beef cattle sales transactions.

Knowledge of the respondents about the bruising and horn damage during beef cattle transportation and sales transaction at the market place (KNOWHWDAMG) captures the importance of monitoring costs incurred when a farmer is trying to minimize bruising, skin and horn damage all through marketing, in an attempt to avoid potential sellers discounting the price they are willing to pay (Hobbs, 1997). As a result, to the extent that such risks are essentially allied with village market outlet sales (i.e. market transportation), it was predicted that such practice could hamper the choice of this market exit. The result presented in Table 1 portrayed that knowledge about such incidents was negligible amongst surveyed respondents. Result shows that only $37.13 \%$ respondents had knowledge of damage in beef cattle transaction.

Trust in buyers (TRUSTINBUYER) takes in to account the opportunity costs of mobilizing the beef cattle producer's time and efforts against the grading and pricing information asymmetry trouble among buyers and sellers. The absence of sellers' participation throughout the grading and price-setting process may create an incentive for the buyer to operate opportunistically (Hobbs, 1997). Therefore, it was expected to influence positively the choice of farm gate sale. The result in Table 1depicted the little trusts between beef cattle producers and buyers. Saying differently, $57.49 \%$ of the respondents are not trusted in buyers in beef cattle transaction. Only $6.59 \%$ of the respondents are trusted in buyers in beef cattle marketing process.

Table 1. Definitions and descriptive statistics for categorical independent variables used in empirical multinomial logit regression model.

\begin{tabular}{|c|c|c|c|c|}
\hline Variables & Variables description & Frequency & $\%$ & Expected sign \\
\hline \multirow{4}{*}{ PRICEINFO } & Not get existing & 51 & 30.54 & \multirow[t]{4}{*}{+} \\
\hline & Get very little & 72 & 43.11 & \\
\hline & Get somehow & 32 & 19.16 & \\
\hline & Get fully & 12 & 7.19 & \\
\hline \multirow[t]{2}{*}{ SEASONSALE } & Sold in pick season of the year & 103 & 61.68 & \multirow[t]{2}{*}{-} \\
\hline & Not sold in pick season & 64 & 38.32 & \\
\hline \multirow[b]{2}{*}{ KNOWBUYER } & Knew the beef cattle buyer & 63 & 37.72 & \multirow[t]{2}{*}{+} \\
\hline & Not knew the buyer & 104 & 62.28 & \\
\hline \multirow[t]{2}{*}{ KNOWHWDAMG } & $\begin{array}{l}\text { Have knowledge of bruising and } \\
\text { horn damage }\end{array}$ & 105 & 62.87 & \multirow[t]{2}{*}{+} \\
\hline & Not have knowledge such things & 62 & 37.13 & \\
\hline \multirow{3}{*}{ TRUSTINBUYER } & No trust in buyers & 96 & 57.49 & \multirow[t]{3}{*}{+} \\
\hline & Somehow trust buyers & 60 & 35.93 & \\
\hline & Total trust in buyers & 11 & 6.59 & \\
\hline
\end{tabular}

Source: Field survey output (2019)

Distance to the livestock market (DISTMARK) shows the cost of transportation that is particular to the cattle market. Hence, the opportunity cost of beef cattle producers and efforts to arrange beef cattle transportation to the cattle market. Nkhori (2004) affirmed that smallholder farmers living in places where roads are not easily accessible might not get updated information relating to the output market prices. In this study, a positive effect of this variable on the choice of farm-gate sales versus village sales was expected. The descriptive result illustrates that, in the sample, the average distance to the cattle market was about $3.9 \mathrm{~km}$ (Table 2).

The rank of beef cattle income in the household's income category (CATTLEINCRANK) shows the degree of producer's specializations, thereby capturing the supply elasticity to up-to-date market information detection, and hence the bargaining power. The study argued that committed or pre-committed producers have lower levels of flexibility in market transactions, giving more market power to the buyers (Bellemare and Barrett, 2006). A priori expectation was a positive effect of this variable on the choice of village market outlet sales versus primary market outlet sales. The result in Table 2 indicated that income from beef cattle sales transactions was, on average, the second most important income source in the respondents' income portfolio, reflecting the significance of commercial motives among surveyed respondents. 
Table 2. Definitions and descriptive statistics for continuous independent variables used in empirical multinomial logit regression model.

\begin{tabular}{|llccccc|}
\hline Variable & $\begin{array}{l}\text { Description } \\
\text { DISTMARK }\end{array}$ & Mean & SD & Min. & Max. & $\begin{array}{c}\text { Expected } \\
\text { sign }\end{array}$ \\
& $\begin{array}{l}\text { Distance to the nearest } \\
\text { livestock market from the } \\
\text { respondent home (in km) }\end{array}$ & 3.871 & 1.847 & 0.5 .000 & 8.0 & + \\
\hline CATTLEINCRAK & $\begin{array}{l}\text { The rank of income from } \\
\text { beef cattle sales in the } \\
\text { household's income range }\end{array}$ & 2.222 & 1.044 & 0.000 & 4.0 & + \\
\hline TLUBEEFCAT & $\begin{array}{l}\text { TLU of beef cattle supplied } \\
\text { to the market during last } \\
\text { three production year }\end{array}$ & 4.772 & 2.505 & 1.000 & 10.0 & + \\
\hline EXPERIANCAT & $\begin{array}{l}\text { Household experience in } \\
\text { beef cattle production and } \\
\text { marketing (in years) }\end{array}$ & 2.725 & 1.862 & 1.000 & 23.0 & - \\
\hline AVELAPRICE & $\begin{array}{l}\text { Average lagged price of } \\
\text { beef cattle }\end{array}$ & 4357.200 & 2342.600800 .000 & 11000.0 & + \\
\hline EDULEV & $\begin{array}{l}\text { Education level of } \\
\text { respondents }\end{array}$ & 4.083 & 3.650 & 0.000 & 12.0 & + \\
\hline HHME & $\begin{array}{l}\text { Household size in man- } \\
\text { equivalent }\end{array}$ & 3.507 & 1.097 & 1.000 & 6.4 & + \\
\hline LANDSIZE & $\begin{array}{l}\text { Respondents cultivated } \\
\text { land size (in qindi) }\end{array}$ & 0.497 & 0.251 & 0.125 & 1 & + \\
\hline
\end{tabular}

Source: Field survey output (2019)

With regard to producer characteristics serving as control variables in the model, the number of beef cattle produced and supplied to the market (TLUBEEFCAT) and cultivated land size (LANDSIZE) affect the motivation of buyers to deal directly with the seller, attracted by economies of scales (Hobbs, 1997). They also serve as a sign of household wealth in the model. As a result, these two variables were intended to control for the associated gains in bargaining power. Experience of the respondents in beef cattle production and marketing activities (EXPERIANCAT) captures the managerial capital of the farm and hence the intensity of internal uncertainty. Education level (EDULEV) captures the role of human capital played in reducing sales transaction costs. The scholars affirmed that household education minimizes the cost of searching for information plus the time-span to process and act on such information (Bywaters and Mlodkowski, 2012). The result in the Table 2 shows that, on average, the respondents were followed junior education and can read and write during the survey time.

\section{Econometric model results}

The results as presented in Table 3 illustrate the factors influencing the choice of beef cattle marketing channels under transaction cost among small-scale farmers' using Multinomial Logit Model. A multicollinarity problem among chosen autonomous variables was tested, and the result of the correlation matrix depicted absence of severe problem in the data set. In addition, the study was employed a classical procedure consisting of using a generalization of the MNL called the nested logit model to test the assumption of independence of irrelevant alternative (IIA) in the MNL model, using a restricted choice set based on the deletion of primary market sales or village market sales, alternative (Hausman and McFadden, 1984). Hence, significant changes in the estimated coefficients were not observed. The result was confirmed following Long and Freese (2006), via the suest-based Hausman test, and the null hypothesis of IIA was not rejected. These pinpointing gives credibility to the model result presented in Table 3.

Concerning information cost variables, the season of beef cattle sales is positive and significant for both alternative market outlets. Selling beef cattle during the pick festive or holiday season of the year is related to $0.99 \%$ and $26.59 \%$ increase in the likelihood of selling at the farm get and village market outlet versus selling at the secondary market outlet, respectively. As the marginal effect suggests, this variable is a major predictor of marketing at the village market outlet in the model. The result explained that an increase in demand for beef cattle during the pick festive or holiday season of the year encourages an amplified number of buyers turning up at the farm get and village market outlet. This finding suggests that increased selling at the farm get and village market outlet is coupled with seasonality allied market uncertainty. If a farmer is not certain about the numbers of buyers turning up at both alternative market outlets, he/she may perceive a high risk of uncompetitive price formation. This perception could significantly trim down his/her readiness 
to incur the cost associated with cattle management at the farm get and transportation of cattle to the village market outlets. This finding approves the view that, by marketing cattle at different times of the year, producers decrease the effect of market seasonality and alleviates the danger of selling in a bad market (Ndoro et al., 2014; Feuz et al., 2013).

With regard to negotiation cost variables, the model result portrayed that the coefficient of knowledge of the buyer is only significant for the choice between selling at the village market versus secondary market outlet. As expected, this result suggests that, with other factors remaining constant, a priori knowledge of a probable buyer amplifies the possibility of selling at a village market outlet versus selling at a secondary market outlet by $18.91 \%$. This finding implies that a harmonious relationship with buyers at the village market outlets reduces the cost of negotiating sales. This finding points out the level to which farmers selling at the village market outlets face superior negation costs. If beef cattle producers' knowledge about the buyer is derived from the prior sale transactions, this result output can also reveal the prevalence of monitoring costs in the sales transaction. This finding substantiates those of Ndoro et al. (2014) who documented that, producers' knowledge of buyers decreases the negotiation costs, as the view of continuing gains from future transactions due to the harmonies relationships between seller and buyer may create incentives for not behaving opportunistically among the buyer.

Table 3. Multinomial logit estimation results.
Unexpectedly, the coefficient of trust in buyer turned out to be negative and significant for selling beef cattle at a village market outlet. Ceteris paribus, trust in buyer decreases the probability of selling beef cattle at village market outlet versus selling at the secondary market outlet by $-24.22 \%$. This may be due to high illegal intervention of brokers, lack of modern weight measurement-based marketing system, and the prevalence of asymmetric information in beef cattle transaction process in the areas. This finding suggests that a trust in buyers increases the cost of monitoring beef cattle transactions at the village market channel.

A number of beef cattle producer characteristics as well found to be significant as depicted in Table 3. Contrary to the a priori expectation, the quantity of beef cattle produced and supplied to the market has a significant effect on selling at the secondary market outlet versus selling at the farm-gate outlet. Making all other variables remaining constant, fattening one more cattle, and adding to supply volume increases the likelihood of selling at the secondary market outlet against farm-gate sales by 4.29. A probable reason is that, as transaction cost minimization objectives go hand in hand with production cost minimization, channel volume is an important factor (McNaughton, 1999). Saying differently, producers are able to spread transaction costs inherent in a market channel over the number of units sold as the channel volume increases. The result corroborates the finding of (Ndoro et al., 2014).

\begin{tabular}{|c|c|c|c|c|c|c|}
\hline \multirow[t]{2}{*}{ Variables } & \multicolumn{3}{|c|}{ Farm get sales } & \multicolumn{3}{|c|}{ Village/primary market sales } \\
\hline & Coefficient & $\begin{array}{l}\text { Marginal } \\
\text { effect }\end{array}$ & $p$ value & Coefficient & $\begin{array}{l}\text { Marginal } \\
\text { effect }\end{array}$ & $p$ value \\
\hline \multicolumn{7}{|l|}{ Information costs } \\
\hline PRICEINFO & -0.322 & -0.0572 & 0.384 & -0.062 & 0.0346 & 0.860 \\
\hline SEASONSALE & 1.196 & 0.0099 & $0.085^{*}$ & 1.791 & 0.2659 & $0.005^{* * *}$ \\
\hline \multicolumn{7}{|l|}{ Negotiation costs } \\
\hline DISTMARK & 0.003 & -0.0002 & 0.689 & 0.005 & 0.0008 & 0.449 \\
\hline KNOWBUYER & 0.675 & 0.0335 & 0.226 & 1.171 & 0.1891 & $0.026^{* *}$ \\
\hline CATTLEINCRANK & -0.098 & -0.0118 & 0.714 & -0.054 & 0.0016 & 0.828 \\
\hline \multicolumn{7}{|l|}{ Monitoring costs } \\
\hline KNOWHWDAMG & 0.175 & 0.0289 & 0.741 & 0.046 & -0.0154 & 0.926 \\
\hline TRUSTINBUYER & -0.408 & 0.1053 & 0.362 & -1.225 & -0.2422 & $0.004^{* * *}$ \\
\hline \multicolumn{7}{|c|}{ Farmers characteristics (i.e. control variables) } \\
\hline TLUBC & -0.261 & -0.0429 & $0.015^{* *}$ & -0.071 & 0.0227 & 0.464 \\
\hline EXPERIANCAT & -0.427 & -0.0297 & $0.006^{* * *}$ & -0.379 & -0.0282 & $0.002^{* * *}$ \\
\hline AVLPRIC & -0.081 & 0.0077 & 0.869 & -0.158 & -0.0269 & 0.727 \\
\hline EDUCAT & 0.447 & 0.0503 & $0.079^{*}$ & 0.273 & -0.0012 & 0.263 \\
\hline HHME & -0.180 & -0.0387 & 0.433 & 0.009 & 0.0301 & 0.966 \\
\hline LANDSIZ & 1.564 & 0.0896 & 0.151 & 1.513 & 0.1348 & 0.138 \\
\hline
\end{tabular}

Source: Model output from field survey (2019)

Note: the number of observations was $n=167, L R \times 2=52.69, p>\chi 2=0.0015$

Hint: Significant levels. ${ }^{*}$ Significant at $10 \%,{ }^{* *}$ Significant at $5 \%,{ }^{* * *}$ Significant at $1 \%$. 
Similar to the a priori expectation, farmers' experience in cattle fattening and marketing has a negative and significant influence on selling at the farm-gate and village market outlets versus selling at the secondary market outlets. Ceteris paribus, farmers adding one more year of cattle fattening and marketing experience decreases the probability of selling at the farm gate and village market outlet versus selling at the secondary market outlet by $2.97 \%$ and $2.82 \%$, respectively. This result shows that experienced farmers are not likely to sell at the farm gate and village market outlet when they are capable of selling at the secondary market outlet. Similar to the hypothetical probability, this result deduces that when beef cattle producers add more managerial and marketing skills through experience, they get the capability to bargain and manage sales transactions at negligible cost. The result agrees with the finding of Ndoro et al. (2014), who argued that as cattle farmers accumulate managerial and marketing skills through experience, they gain an ability to coordinate market transactions at a much-reduced cost. Contrary to this, Nxumalo et al. (2019), and Kirui et al. (2016), reported a negative effect of an increase in farming experience on farmers decision to participate in a choice of formal marketing channel.

Finally, the results show a significantly positive coefficient of farmer's level of education on the choice of farm gate market outlets versus secondary market outlets. Ceteris paribus, a oneyear increase in farmers' education level increases the probability of selling at the farm gate market outlet versus selling at the secondary market outlet by $5.03 \%$. This result indicates that as the educational level of farmers increases, their choice of secondary market outlet channels decreases. In other words, the study result depicted that education has an implication on the ability to process, understand, and interpret market information received by an individual cattle farmer. The result is in line with the finding of Jari and Fraser (2009), who explained that educational levels affect the interpretation of market information and choice; hence, this influences the level of participation and the choice of the market channel. Besides, the result corroborated with the finding of Nxumalo et al. (2019), who reported that increases in the educational level of farmers decrease their participation in formal market outlets. Moreover, according to the finding of Marenya and Barrett (2007), formal education enhances managerial competence and successful implementation of improved production, processing, and marketing practices.

\section{Conclusions and Recommendations}

Smallholder farmers' association to diverse marketing channels can be understood through transaction cost approach, which suggests key policy recommendations. Contrasting to prior studies that offer descriptive, case specific information regarding various transaction costs incurred by smallholder farmers in different rural areas of the country, the aim of this research is to analyze more meticulously beef cattle marketing channel choice under transaction costs. The hypothetical predictions about the effects of information, negotiation and monitoring costs on smallholder farmers' decision on whether to sell their beef cattle at the farm get, village market or secondary market outlets were tested based on primary data collected from 171 beef cattle producers selected through multistage sampling techniques.

The descriptive result indicated that most respondents (49\%) were selling at the village market outlets, followed by farm gate and secondary market outlet sales with $28 \%$ and $23 \%$, respectively. In addition, Multinomial logit estimation results revealed some imperative outcomes. Regarding season of beef cattle sale, the results point out that the likelihood of selling at the farm get and village market outlet was increased as compared to selling at the secondary market outlet. This may be due to market uncertainty during the festive/holiday season that drives smallholder farmers to self-select out of the existing beef cattle marketing channels. The result also revealed that, regarding negotiations cost variables, a priori knowledge of a probable buyer amplifies the possibility of selling at the village market outlet versus secondary market outlet, which may be due to harmonious relationship with buyers at the village market, hence, reduces the cost associated with negotiating transactions. Surprisingly, the result indicated that trust in buyer turned out to be negatively associated with selling beef cattle at the village market outlet. Thus, the likelihood of selling beef cattle at the village market versus secondary market outlet decreased which may be due to high illegal intervention of brokers, lack of modern marketing system, and the prevalence of asymmetric information, and then increases monitoring costs at the village market channels.

The study result has an important implication for cattle marketing process in the study areas in particular and the country in general. Any strategists related to cattle marketing system should explicitly take into account the transaction costs approaches. The market uncertainty and higher negotiation costs associated with cattle marketing at the village market outlet signify the need to investigate the viability of alternative types of beef cattle marketing channels that mitigate the market uncertainty, illegal broker interventions, and asymmetric information and reduce the chance of non-sale. This also requires concurrent efforts to improve overall cattle marketing channels in the area in order to reduce the gap between smallholder farmers' expected prices and the buyers' prices. The prevalence of information and monitoring costs associated with selling beef cattle at the farm get and village market channels requires the development of institutional environments through which market coordination and smooth enforcing mechanisms can thrive. Besides, dynamic incentives in the form of trust-based relational exchanges offer an appropriate means for minimizing the scope for opportunism among the itinerant market participants. Lastly, the concerned stakeholders will have to devise platforms to facilitate the formation of smallholder farmers' controlled livestock marketing cooperatives, which may help them reduce transaction costs in marketing channels in the study areas. 


\section{Acknowledgements}

The authors thank the University of Oda Bultum for the financial support for the study. In addition, the advisory support of different friends is appreciated. The authors also extend their recognitions to technicians who worked tirelessly in data collection.

\section{References}

Arinloye, D.D, Pascucci S., Linnemann, A.R., Coulibaly, O.N., Hagelaar, G. and Omta, O.S. 2015. Marketing channel selection by smallholder farmers. J. Food Prod. Mark. 21(4): 337-57.

https://doi.org/10.1080/10454446.2013.856052

Barrett, C.B. 2008. Smallholder market participation: concepts and evidence from eastern and southern Africa. Food Policy. 33: 299-317.

https://doi.org/10.1016/j.foodpol.2007.10.005

Barrett, C.B. and Swallow, B. 2006. Fractal poverty traps. World Dev. 34(1): 1-15.

https://doi.org/10.1016/j.worlddev.2005.06.008

Bassolet, B. 2000. Libe'ralisation du Marche' Ce're'alier au Burkina Faso: une Analyse $\mathrm{Ne}^{\prime}$-institutionelle de son Organisation et de son Efficacite' Temporelle et Spatiale [Liberalization of cereal market in Burkina Faso: A neo-institutional analysis of its organization and its effectiveness' temporal and spatial]. PhD Thesis. University of Groningen, the Netherlands.

Bellemare, M.F. and Barrett, C.B. 2006. An ordered Tobit model of market participation: evidence from Kenya and Ethiopia. American J. Agril. Econ. 88: 324337.https://doi.org/10.1111/j.1467-8276.2006.00861.x

Binti Man, N., Kadhim, Z.R., Abd Latif, I. and Seng, K.W.K. 2017. The role and importance of the transactions costs theory in agricultural contracting area: an appraisal of selected empirical studies. J. Bus. Manage. 19(1): 79-89: https://doi.org/10.9790/487X1901057989

Bywaters, D. and Mlodkowski, P. 2012. The role of transactions costs in economic growth. Int. J. Econ. Policy. Stud. 7: 53-66.

Coase, R. 1937. The nature of the firm. Economica. 4(16): 386-405. https://doi.org/10.1111/j.1468-0335.1937.tboooo2.x

CSA. 2017. Summery and Statistical Report of the projected 2017 Population and Housing Census. Central Statistical Agency, Federal Democratic Republic of Ethiopia Population Census Commission, Addis Ababa, Ethiopia.

DDOA. 2014. Reports of Doba District Office of Agriculture, Doba District Office of Agriculture. Oromia, Ethiopia.

De Bruyn, P., De Bruyn, J.N., Vink, N. and Kirsten J.F. 2001. How transaction costs influence cattle marketing decisions in the northern communal areas of Namibia. Agrekon. 40(3): 405-425.

https://doi.org/10.1080/03031853.2001.9524961

Degye, G., Belay, K. and Mengistu, K. 2013. Is food security enhanced by agricultural technologies in rural Ethiopia? African $J$. Agric. Resour. Econ. 8(1): 58-68.
Dougherty, C. 1992. Introduction to Econometrics. Oxford University.

Feuz, DM., Feuz, B. and Feuz, R. 2013. Livestock marketing and risk management. Logan: Utah State University, Cooperative Extension. Conference paper.

GDOA. 2014. Reports of Gemechis District Office of Agriculture, Gemechis District Office of Agriculture Oromia, Ethiopia.

Gong, W., Parton, K., Cox, R.J. and Zhou, Z. 2007. Transaction costs and cattle producers' choice of marketing channels in China. Manage. Res. News. 30(1): 47-57.

Gong, W., Parton., K., Cox, R.J. and Zhou, Z. 2006. Transaction costs and cattle farmers' choice of marketing channels in China: a Tobit analysis. Manage. Res. News. 30: 4756. https://doi.org/10.1108/01409170710724296

Greene, W.H. 2003. Econometric analysis (5 ed.). Englewood Cliffs: Prentice Hall.

Gujarati, D. 1992. Essentials of Econometrics. New York: MacGraw-Hill.

Hausman, J. and McFadden, D. 1984. Specification tests for the multinomial logit model. Econometrica. 52: 1219-1240. https://doi.org/10.2307/1910997

Hausman, J.A., and Wise, D.A. 1978. A conditional probit model for qualitative choice: Discrete decisions recognizing interdependence and heterogeneous preferences. Econometrica. 46: 403-426. https://doi.org/10.2307/1913909

Hobbs, J.E. 1996. Transaction costs and slaughter cattle procurement: processors' selection of supply channels. Agribusi. 12(6):509-523.https://doi.org/10.1002/(SICI)15206297(199611/12)12:6<509::AID-AGR2>3.0.CO;2-7

Hobbs, J.E. 1997. Measuring the importance of transaction costs in cattle marketing. American J. Agril. Econ. Assoc. 79(4): 1083-1095. https://doi.org/10.2307/1244266

IFAD. 2003. Promoting Market Access for the Rural Poor in Order to Achieve the Millennium Development Goals. Discussion Paper. Rome.

Jabbar, M., Benin, S., Gabre-Madhin, E, and Paulos Z. 2008. Market institutions and transaction costs influencing trader performance in live animal marketing in rural Ethiopian markets. J. African Econ. 17(5): 747-764.

https://doi.org/10.1093/jae/ejnoo4

Jagwe, J., Machethe, C. and Ouma, E. 2010. Transaction costs and smallholder farmers' participation in banana markets in the Great Lakes Region of Burundi, Rwanda and the Democratic Republic of Congo. African $J$. Agril. Res. 6(1): 1-16.

Jari, B. and Fraser, G.C.G. 2009. An Analysis of Institutional and Technical Factors Influencing Agricultural Marketing amongst Smallholder Farmers in the Rift Valley, Eastern Cape Province, South Africa. African J. Agril. Res. 4: 1129-1137.

Jorine, T.N., Maxwell, M. and Michael, C. 2015. Farmers' choice of cattle marketing channels under transaction cost in rural South Africa: a multinomial logit model, African J. Range Forage Sci. 32(4): 243-252.

http://dx.doi.org/10.2989/10220119.2014.959056 
Key, N., Elisabeth, S. and Alain, D.J. 2000. Transaction Costs and Agricultural Household Supply Response. American $J$. Agril. Econ. 82: 245-259.

Kirui, H., Mutai, K.B., Kibet, K.L., Kibet, R.P. and Macharia, A. 2016. Determinants of tea marketing channel choice and sales intensity among smallholder farmers in Kericho District, Kenya. J. Econ. Sustain. Dev. 7(7): $107-114$.

Long, J.S. and Freese, J. 2006. Regression Models for Categorical Dependent Variables Using Stata $\left(2^{\text {nd }}\right.$ ed.). College Station, TX: Stata Press.

MacInnis, D. 2004. Where have all the papers gone? Association for Consumer Research Newsletter, University of Southern California Spring. pp. 1-16.

Makhura, M., Kirsten, J. and Delgado, C. 2001. Transaction costs and smallholder participation in the maize market in the Northern Province of South Africa, Seventh Eastern and Southern African Regional Maize Conference. pp. 463-462.

Marenya, P.P. and Barrett, C.B. 2007. Household-level determinants of adoption of improved natural resources management practices among smallholder farmers in western Kenya. Food Policy. 32(4): 515-536. https://doi.org/10.1016/j.foodpol.2006.10.002

McNaughton, R.B. 1999. Transaction cost analysis and the methodology of foreignmarket entry-mode studies. Environ. Plann. A 31: 575-596.

Musemwa, L., Mushunje, A., Chimonyo, M., Frazer, G., Mapiye, C. and Muchenje, V. 2008. Nguni cattle marketing constraints and opportunities in the communal areas of South Africa: Review. African J. Agril. Res. 3(4): 239-245.

Ndoro, J.T, Mudhara, M. and Chimonyo, M. 2014. Cattle commercialization in rural South Africa: livelihood drivers and implications for livestock marketing extension. J. Human Ecol. 45: 207-221.

Nkhori, P.A. 2004. The impact of transaction costs on the choice of cattle markets in Mahalapye district, Botswana. M.Sc. thesis. Department of Agricultural Economics, Extension and Rural Development, University of Pretoria.

Nxumalo, K.K.S., Oduniyi, O.S, Antwi, M.A. and Tekana, S.S. 2019. Determinants of market channel choice utilized by maize and sunflower farmers in the North West province, South Africa. Cogent Soc. Sci. 5: 1678451.

https://doi.org/10.1080/23311886.2019.1678451

Otieno, D.J., Omiti, J., Nyanamba, T. and McCullough, E. 2009. Market participation by vegetable farmers in Kenya: A comparison of rural and peri-urban areas. African J. Agril. Res. 4(5): 451-460.

Reddy, C.S.P. and Kanna, V.N. 2015. Market and value chain analysis of cattle and beef in Ethiopia -A Review. Int. J. Soc. Sci. Arts Human. 1(2): 51-66.
Ruijs, A., Schweigman, C. and Lutz, C. 2004. The impact of transport and transaction-cost reductions on food Markets in Developing Countries: Evidence from Tempered Expectations for Burkina Faso. Agril. Econ. 31(2-3): 219-228. https://doi.org/10.1111/j.1574-

Shiimi, T., Taljaard, P.R. and Jordaan, H. 2012. Transaction costs and cattle farmers' choice of marketing channel in North-Central Namibia. Agrekon. 51: 42-58. https://doi.org/10.1080/03031853.2012.649543

Singh, N. 2008. Transaction Costs, Information Technology and Development, University of California, Santa Cruz, MPRA Paper No. 9095, posted 13, 07: 15 UTC. https://mpra.ub.uni-muenchen.de/9095/

Siziba, S., Nyikahadzoi, K., Diagne, A., Fatunbi, A.O. and Adekunle, A.A. 2011. Determinants of cereal market participation by subSaharan Africa smallholder farmer. Learning Publics J. Agric. Environ. Stud. 2(1): 180-193.

Staal, S., Delgado, C. and Nicholson, C. 1997. Smallholder dairying under transactions costs in East Africa. World Dev. 25(5): 779794 .

https://doi.org/10.1016/So305-750X(96)oo138-6

Takeshima, H. 2008. Behavior of subsistence producers in response to technological change-the elasticity of cassava production and home consumption on Benin. Selected Poster prepared for presentation at the American Agricultural economics association Annual Meeting, Orlando, Fl, July 27-29, 2008.

Teklewold, H., Legese, G., Alemu, D. and Negassa, A. 2008. Live animal and meat export value chains for selected areas in Ethiopia: Constraints and opportunities for enhancing meat exports. ILRI Discussion Paper 12. ILRI (International Livestock Research Institute), Nairobi, Kenya.

Tse, Y.K. 1987. A diagnostic test for the multinomial logit model. J. Busi. Econ. Stat. 5(2): 283-286. https://doi.org/10.1080/07350015.1987.10509587

Wooldridge, J.M. 2002. Econometric analysis of cross section and panel data. Cambridge, Massachusetts: MIT Press.

$\mathrm{Wu}, \mathrm{J}$. and Babcock, B.A. 1998. The choice of tillage, rotation, and soil testing practices: Economic and environmental implications. American J. Agril. Econ. 80(3): 494-511. https://doi.org/10.2307/1244552

Yacob, A. and Catley, A. 2010. Livestock Exports from Pastoralist Areas: An Analysis of Benefits by Wealth Group and Policy Implications. IGAD LPI Working Paper No. 01-10: 52.

Yamane, T. 1967. Elementary sampling theory. Englewood Cliffs: Printice Hall Inc.

Yu, L., Hurley, T., Kliebenstein, J. and Orazen, P. 2008. Testing for complementarities and substitutability among multiple technologies: the case of US Hog Farms. Working paper, No. 08026. Ames, IA, USA: Iowa State University, Department of Economics. 